\title{
Varietal Influence on Phosphorus Uptake and Use Efficiency in Soybean at Varying Phosphorus Regimes in Vertisols of Central India
}

\author{
S. Neenu ${ }^{1^{*}}$, K. Ramesh ${ }^{2}$, J. Somasundaram ${ }^{3}$ and S. Ramana ${ }^{3}$ \\ ${ }^{1}$ Crop Production Division, Central Plantation Crops Research Institute, \\ Kasaragod, India \\ ${ }^{2}$ Indian Institute of Oil Seed Research, Hyderabad, India \\ ${ }^{3}$ Indian Institute of Soil Science, Bhopal, India-462 038, India \\ *Corresponding author
}

\section{A B S T R A C T}

Keywords

Soybean,

Phosphorus,

Varieties, Uptake,

PUE, Phosphorus

harvest index

Article Info

Accepted:

20 May 2020

Available Online:

10 June 2020
A field experiment was carried out in Indian Institute of Soil Science, Bhopal to study the effect of different dose of phosphorus on the phosphorus acquisition pattern in different varieties of soybean (Glycine $\max$ L.) under rainfed conditions in black soil. The experiment was laid out in factorial RBD with 3 replications. There were four phosphorus levels viz. $0,30,60$ and $90 \mathrm{~kg} \mathrm{ha}^{-1}$ phosphorus and four varieties of soybean viz., JS 9560, JS 9305, JS 335 and JS 9752. The results revealed that the variety JS 9752 is better in phosphorus acquisition and yield. Grain yield showed a linear increase only up to $60 \mathrm{~kg} \mathrm{ha}^{-1}$ phosphorus in all the varieties. Among the varieties, JS 9752 has given the highest grain yield on supply of $60 \mathrm{~kg}$ $\mathrm{ha}^{-1}$ phosphorus. Phosphorus uptake and use efficiency were also were highest for the variety JS 9752 followed by JS 9560 in all the treatments. Hence it is concluded that JS 9752 is the most efficient variety among the four in terms of yield and phosphorus uptake followed by JS 9560.

\section{Introduction}

Soybean (Glycine max (L.) Merrill) know as the 'Golden bean or the Super bean' of the twentieth century is one of the main oil yielding crops in the world. Soybean belongs to the family Leguminosae, sub-family Papilionaceae and the genus Glycine. The crop has a well-known place as the world's most important seed legume, which accounts
$25 \%$ to the global vegetable oil production, about two thirds of the world's protein concentrate for livestock feeding and is a major constituent in formulated feeds for poultry and fish. Soybean plays a crucial role in agricultural economy of India. Annually about $85 \%$ of the world's soybeans are processed into soybean meal and oil. Soybean oil plays a good role as edible oil as well as raw material in industries like soap and 
biodiesel production. Soybean contributes substantially to the Indian edible oil pool and currently soybean contributes $43 \%$ to the total oilseeds and $25 \%$ to soybean in the world.

In India soybean is traditionally grown in the 'Kharif' or monsoon season as a rainfed crop and assumed as one of the most stable kharif pulses under different agro-climatic conditions (Kumar et al., 2008). Among the Indian states, Madhya Pradesh is known as the 'soybean belt' which alone accounts for $81 \%$ of the area under soybean cultivation. Among the Indian states, Maharashtra and Madhya Pradesh are the major soybean producers and about 89 per cent of the total production is contributed by these states. Soybean can improve soil fertility by fixing atmospheric nitrogen through root nodules. Low productivity of soybean in India is due to several constraints, one among the important is unbalanced nutrition (Sharma et al., 1996).

Soybean can be grown on almost all welldrained soils; although, the crop is more productive on fertile loam soils. Plant nutrition is a important input to boost the productivity of soybean crop. Phosphorus is one of the limiting plant nutrients for production of soybean (Rao et al., 1995). Phosphorus has a wide range of functions in plant processes from permitting cell division to development of good root system. Pod setting, seed formation and protein synthesis are major functions of phosphorus in pulses. Phosphorus uptake and utilization by soybean crop is important for ensuring proper growth and maintaining good quality and yield of the crop. Phosphorus deficiency can cause a limit nodulation in legumes and $\mathrm{P}$ fertilizer application can overcome this deficiency (Carsky et al., 2001).

Phosphorus has consistently increased grain yield of soybean on phosphorus deficient soils (Pal et al., 1983; Chiezey et al., 1991) as it also encourages production and retention of more pods per plant (Chiezey, 2001).

In general phosphorus fertilizers have low efficiency of utilization due to chemical fixation in soil (Russell, 1973). Low phosphorous availability is a major constraint to soybean growth and production. Alongside, there will be a great shortage of $\mathrm{P}$ fertilizer resources as the $\mathrm{P}$ deposits are depleting in an alarming rate (Yan et al., 2009). Hence, developing new varieties with high $P$ efficiency or find out $\mathrm{P}$ efficient varieties in the existing varietal germplasm, that can utilize native $\mathrm{P}$ and added $\mathrm{P}$ in the soil would be a sustainable and cost-effective approach to soybean production. Keeping these views, the present investigation was carried out to study the performance of different soybean cultivars at varying $\mathrm{P}$ regimes through applied $\mathrm{P}$ fertilizer.

\section{Materials and Methods}

\section{Experimental site and soil}

The field experiment was conducted at Indian Institute of Soil Science, Bhopal (Between $23^{\circ} 18^{\prime} 14^{\prime \prime}$ and $23^{\circ} 18^{\prime} 48^{\prime \prime} \mathrm{N}$ latitude and $77^{\circ} 24^{\prime} 17^{\prime \prime}$ and $77^{\circ} 24^{\prime} 58^{\prime \prime}$ E longitude on Vindhyan plateau of western Madhya Pradesh) to study the effect of different phosphorus levels viz., 0, 30, 60 and 90 $\mathrm{kg} \mathrm{ha}^{-1}$ on phosphorous acquisition and use efficiency of four major varieties of soybean in Vertisols of central India. The experimental soil contained $5 \mathrm{~g} \mathrm{~kg}^{-1}$ organic carbon, 110.27 ppm nitrogen, $1.6 \mathrm{ppm}$ available phosphorus and $250.6 \mathrm{ppm}$ available $\mathrm{K}$ with $\mathrm{pH} 8.35$. The experiment was conducted in a factorial randomized complete block design with plot size $3.0 \mathrm{~m} \times 5.0 \mathrm{~m}$ and replicated thrice. Seedbed was prepared by 2-3 times ploughing followed by planking. Four varieties of soybean viz., JS 9560, JS 9752, JS 9305 and JS 335 as V1, V2, V3 and V4 respectively 
were used for the study. The breeder seeds of these different varieties were collected from Directorate of Soybean, Indore. The sowing was done manually with seed rate of $80 \mathrm{~kg}$ ha 1 at a row to row distance of $45 \mathrm{~cm}$.

\section{Fertilizer application and other cultural practices}

A recommended starter dose of $\mathrm{N} @ 20 \mathrm{~kg}$ $\mathrm{ha}^{-1}, \mathrm{~K} @ 20 \mathrm{~kg} \mathrm{ha}^{-1}$ and Zn@ $5 \mathrm{~kg} \mathrm{ha}^{-1}$ were applied at sowing time as Urea $(46 \% \mathrm{~N})$, Muriate of Potash $\left(50 \% \quad \mathrm{~K}_{2} \mathrm{O}\right)$ and Zinc Sulphate $(21 \% \mathrm{Zn}$ and $18 \% \mathrm{~S})$. Phosphorus was applied at four graded levels $(\mathrm{P} 1: 0 \mathrm{~kg}$, P2: $30 \mathrm{~kg}, \mathrm{P} 3: 60 \mathrm{~kg}$ and P4: $90 \mathrm{~kg} \mathrm{P}_{2} \mathrm{O}_{5} \mathrm{ha}^{-1}$ ) supplied through single super phosphate $(16 \%$ $\mathrm{P}_{2} \mathrm{O}_{5}$ ). Thinning was done at 15 days after germination to maintain a plant to plant distance of $10 \mathrm{~cm}$ and optimum plant population. Hoeing was done thrice to keep the crop weed free. No irrigation was given as the crop was raised as rainfed crop. All other cultural practices were kept normal and uniform for all the treatments. Different varieties were harvested on different dates according to their maturity (Table 1).

\section{Data recording and analysis}

Five plants were selected at random from each net plot for recording observation. Days to $50 \%$ flowering was recorded by counting the total number of days required for $50 \%$ of the total population to reach flowering stage, days to physiological maturity was recorded by counting number of days required the entire plants to reach yellow and dry stage and grain yield by taking the total seed yield plant $^{-1}$ from each treatment. For nutrient analysis the plant samples were collected by uprooting 5 plants randomly at physiological maturity and dried in the oven at $70^{\circ} \mathrm{C}$ and samples were powdered separately as leaf, stem, pod and grain for total phosphorus analysis. Phosphorus content in the plant parts were analyzed by vanado-molybdophosphoric yellow colour method (Jackson, 1973). The uptake of nutrients was calculated by multiplying the plant/ seed dry weight in $\mathrm{kg}$ $\mathrm{ha}^{-1}$ and nutrient concentration in the respective plant part divided by 100 . The phosphorus use efficiency (PUE) was calculated by dividing the yield and phosphorus in soil. The phosphorus uptake efficiency (PUpE) was calculated as phosphorus in plant divided by phosphorus in soil. The phosphorus harvest index was calculated by dividing the grain phosphorus uptake by total phosphorus uptake. Statistical analysis of the data was done as per the procedure given by Gomez and Gomez (1984). The weather data during the experiment is presented in Figure 1.

\section{Results and Discussion}

Days to $50 \%$ flowering and physiological maturity showed significant difference between varieties as well as phosphorus doses (Table 2). The duration required for flowering and maturity primarily depend on the genetic makeup of the variety (Hodges and French, 1985). But environmental factors like photoperiods, light intensity, temperature etc also affect the time of flowering and maturity of soybean (Miladinovic and Dordevic, 2011). In this study it was observed that the treatment with no phosphorus took more time for flower initiation and 50\% flowering. Similar findings were observed by Julia et al., (2016) in rice.

As the phosphorus dose increased, the total time required to reach $50 \%$ flowering as well as physiological maturity showed a linear decrease up to P3 (60 kg ha $\left.{ }^{-1}\right)$ phosphorus in all the varieties. The highest dose of P4 (90 $\mathrm{kg} \mathrm{ha}^{-1}$ ) slightly increased the days to reach flowering and maturity. Among the four varieties JS 9560 showed the lowest duration for both flowering and maturity as it is a short 
duration variety. Those varieties received lower doses of phosphorus took fewer number of days to flowering. This corroborates the findings of Chauhan et al., (1992) reported that phosphorus deficiency reduced the crop growth, delayed flowering and maturity in pigeon pea. The interaction effect of variety and phosphorus treatment is not significant in case of days to physiological maturity.

The phosphorus content in leaf and stem showed significant difference between phosphorus doses as well as varieties (Figure 2). As the phosphorus doses increased the phosphorus content of leaf and stem also increased. The highest phosphorus content recorded in $\mathrm{P} 4\left(90 \mathrm{~kg} \mathrm{P}_{2} \mathrm{O}_{5} \mathrm{ha}^{-1}\right)$ treatment in all the varieties. These findings are in agreement with that of Pal et al., (1989). The variety JS 9752 showed a higher leaf phosphorus status even in the low doses of phosphorus supply, at the same time the stem phosphorus content showed a marked decrease compared to other varieties in all the phosphorus treatments. According to Park et al., (2000) it was the stem $\mathrm{P}$ which decide the $\mathrm{P}$ storage in leaf and other tissues. The variety JS 9305 showed the highest content of stem phosphorus in all the treatments followed by JS 335. A study conducted by Furlani et al., (2002) reported that the most $\mathrm{P}$ efficient genotypes showed a lower phosphorus concentration in their stem tissues. Here the variety JS 9752 recorded the lowest stem phosphorus content.

The phosphorus content of pod and grain showed significant difference between phosphorus treatments and varieties (Figure 3 ). The lowest pod and grain phosphorus content was recorded in treatment with no phosphorus application in all the varieties. Also there was a gradual increase in pod and grain $\mathrm{P}$ from $\mathrm{P} 2$ to $\mathrm{P} 4\left(30 \mathrm{~kg} \mathrm{ha}^{-1}\right.$ to 90 $\mathrm{kg} \mathrm{ha}^{-1}$ ) irrespective of varieties. According to Saha et al., (2005) increasing levels of phosphorus significantly increased the grain and plant phosphorus content. The highest content of pod phosphorus was recorded by the variety JS 9560 followed by JS 9752 in all the treatments. The grain $\mathrm{P}$ was the highest for the variety JS 9305 followed by JS 9560. The lowest grain phosphorus content was recorded by the variety JS 9752 followed by JS 9305. The effective translocation of $P$ from leaves and stems to grain was not taken place in the variety JS 9752. According to Park et al., (2000) the stem tissue, regulate the $\mathrm{P}$ concentration of leaves, which in turn strongly depends on the supply of P. But the variety JS 9305 was effectively mobilized the leaf and stem $\mathrm{P}$ to grain and hence recorded a higher grain $P$. There is no significant difference between the interaction effect of variety and phosphorus treatments in case of grain $\mathrm{P}$.

The total dry matter production was found significantly different between varieties and treatments (Table 3). The highest total dry matter production was recorded by the variety JS 9752 followed by JS 9560. The lowest dry matter production was recorded by the variety JS 9305 followed by JS 335. The biomass distribution pattern is a biological trait that mainly depends on genotype and will affect growth, development and yield of the individual population (Ao et al., 2013). In case of phosphorus treatments there is a linear increase in dry matter production was recorded and the highest was for P4 $(90 \mathrm{~kg}$ $\mathrm{P}_{2} \mathrm{O}_{5} \mathrm{ha}^{-1}$ ) treatment. According to Cai et al., (2004) phosphorus application has a direct effect on soybean biomass yield but excess $P$ application may suppress the growth. The treatment with no phosphorus application recorded the lowest biomass production in all varieties. This is in confirmation with the findings of Julia et al., (2016). Those varieties with greater dry matter production at low $\mathrm{P}$ conditions are considered as $\mathrm{P}$ efficient genotypes. In this study the variety JS 9752 
recorded the highest dry matter production at the lowest supply of $\mathrm{P}\left(0 \mathrm{~kg} \mathrm{ha}^{-1}\right)$ followed by JS 9560. So these varieties are $\mathrm{P}$ efficient varieties and can be used in breeding programmes also. Higher $\mathrm{P}$ acquisition through root exudation of organic acids under $P$ starvation condition also reported in soybean by several researchers (Dong et al., 2004; Dinkelaker et al., 1989; Johnson et al., 1996).

Table.1 Varietal characters used in the study

\begin{tabular}{|c|c|c|c|c|}
\hline \multirow{2}{*}{ Character } & \multicolumn{4}{|l|}{ Varieties } \\
\hline & JS 9560 & JS 9752 & JS 9305 & JS 335 \\
\hline Duration & $85-90$ & $98-102$ & $90-95$ & $95-100$ \\
\hline $\begin{array}{l}\text { Potential Yield } \\
\left(\mathrm{q} \mathrm{ha} \mathrm{a}^{-1}\right)\end{array}$ & $25-30$ & $25-30$ & $20-25$ & $25-30$ \\
\hline Growth habit & $\begin{array}{l}\text { Determinate, } \\
\text { very small } \\
\text { pubescence, } \\
\text { susceptible to } \\
\text { drought }\end{array}$ & $\begin{array}{l}\text { Semi } \\
\text { determinate, } \\
\text { pods and } \\
\text { stem are } \\
\text { pubescent }\end{array}$ & $\begin{array}{l}\text { Semi determinate, } \\
\text { resistant to shattering, } \\
\text { have very small and } \\
\text { spares pubescence on } \\
\text { stem and leaves, } \\
\text { glabrous pods. }\end{array}$ & $\begin{array}{l}\text { Semi determinate, } \\
\text { resistant to } \\
\text { shattering, } \\
\text { glabrous pods, } \\
\text { yellow seed coat. }\end{array}$ \\
\hline Flower Colour & Purple flower & White flower & Purple colour & Purple flower \\
\hline
\end{tabular}

Table.2 Days to 50\% flowering and physiological maturity (Days)

\begin{tabular}{|c|c|c|c|c|c|c|c|c|c|c|}
\hline \multicolumn{6}{|c|}{ Days to $50 \%$ flowering } & \multicolumn{5}{|c|}{ Days to physiological maturity } \\
\hline \multicolumn{6}{|c|}{ Phosphorus levels $\left(\mathrm{kg} \mathrm{ha}^{-1}\right)$} & \multicolumn{5}{|c|}{ Phosphorus levels $\left(\mathrm{kg} \mathrm{ha}^{-1}\right)$} \\
\hline Variety & P1 & P2 & P3 & P4 & Mean & P1 & P2 & P3 & P4 & Mean \\
\hline JS 9560 & 36.7 & 36.0 & 35.7 & 36.3 & 36.2 & 85.3 & 84.7 & 84.3 & 86.3 & 85.2 \\
\hline JS 9752 & 59.0 & 57.0 & 54.3 & 56.3 & 56.7 & 97.7 & 97.0 & 96.0 & 99.0 & 97.4 \\
\hline JS 9305 & 52.0 & 49.0 & 47.0 & 47.7 & 48.9 & 96.7 & 96.3 & 95.3 & 97.3 & 96.4 \\
\hline JS 335 & 54.3 & 54.3 & 48.0 & 49.0 & 51.4 & 95.7 & 95.3 & 94.3 & 98.3 & 95.9 \\
\hline Mean & 50.5 & 49.1 & 46.3 & 47.3 & & 93.3 & 92.8 & 92.2 & 94.4 & \\
\hline Source & $\mathrm{SE}(\mathrm{m})$ & \multicolumn{2}{|c|}{$\mathrm{CD}(\mathrm{p}=0.05)$} & & & $\mathrm{SE}(\mathrm{m})$ & \multicolumn{2}{|c|}{$\begin{array}{l}\mathrm{CD} \\
(\mathrm{p}=0.05)\end{array}$} & & \\
\hline Variety & 0.236 & 0.685 & & & & 0.203 & 0.59 & & & \\
\hline P level & 0.236 & 0.685 & & & & 0.203 & 0.59 & & & \\
\hline V X P & 0.472 & 1.37 & & & & 0.407 & N/A & & & \\
\hline
\end{tabular}


Table.3 Total DMP and Total Phosphorus uptake as affected by treatments

\begin{tabular}{|c|c|c|c|c|c|c|c|c|c|c|}
\hline \multicolumn{6}{|c|}{ Total DMP (g plant $\left.{ }^{-1}\right)$} & \multicolumn{5}{|c|}{ Total phosphorus uptake $\left(\mathrm{kg} \mathrm{ha}^{-1}\right)$} \\
\hline \multicolumn{6}{|c|}{ Phosphorus levels $\left(\mathrm{kg} \mathrm{ha}^{-1}\right)$} & \multicolumn{5}{|c|}{ Phosphorus levels $\left(\mathrm{kg} \mathrm{ha}^{-1}\right)$} \\
\hline Variety & P1 & P2 & $\mathbf{P 3}$ & P4 & Mean & P1 & $\mathbf{P 2}$ & $\mathbf{P 3}$ & P4 & Mean \\
\hline JS 9560 & 11.72 & 21.86 & 24.35 & 24.22 & 20.54 & 5.85 & 11.58 & 14.14 & 15.44 & 11.75 \\
\hline JS 9752 & 15.17 & 25.76 & 31.80 & 32.09 & 26.20 & 6.29 & 13.18 & 17.72 & 18.93 & 14.03 \\
\hline JS 9305 & 10.51 & 18.45 & 20.71 & 21.67 & 17.83 & 6.29 & 11.46 & 13.72 & 14.79 & 11.56 \\
\hline JS 335 & 11.20 & 19.55 & 23.46 & 23.12 & 19.33 & 5.20 & 10.06 & 13.45 & 14.15 & 10.71 \\
\hline Mean & 12.15 & 21.40 & 25.08 & 25.27 & & 5.91 & 11.57 & 14.76 & 15.83 & \\
\hline Source & $\mathrm{SE}(\mathrm{m})$ & \multicolumn{2}{|c|}{$\mathrm{CD}(\mathrm{p}=0.05)$} & & & $\mathrm{SE}(\mathrm{m})$ & \multicolumn{2}{|c|}{$\mathrm{CD}(\mathrm{p}=0.05)$} & & \\
\hline Variety & 0.10 & 0.30 & & & & 0.09 & 0.27 & & & \\
\hline P level & 0.10 & 0.30 & & & & 0.09 & 0.27 & & & \\
\hline VXP & 0.21 & 0.59 & & & & 0.18 & 0.53 & & & \\
\hline
\end{tabular}

Table.4 Grain yield and Harvest Index as affected by treatments

\begin{tabular}{|c|c|c|c|c|c|c|c|c|c|c|}
\hline \multicolumn{6}{|c|}{ Grain Yield $\left(\mathrm{g} \mathrm{plant}^{-1}\right)$} & \multicolumn{5}{|c|}{ Harvest Index } \\
\hline \multicolumn{6}{|c|}{ Phosphorus levels $\left(\mathrm{kg} \mathrm{ha}^{-1}\right)$} & \multicolumn{5}{|c|}{ Phosphorus levels $\left(\mathrm{kg} \mathrm{ha}^{-1}\right)$} \\
\hline Variety & P1 & P2 & P3 & $\mathbf{P 4}$ & Mean & P1 & $\mathbf{P 2}$ & $\mathbf{P 3}$ & $\mathbf{P 4}$ & Mean \\
\hline JS 9560 & 3.36 & 6.47 & 7.63 & 7.14 & 6.15 & 0.29 & 0.29 & 0.31 & 0.29 & 0.30 \\
\hline JS 9752 & 3.89 & 7.75 & 9.92 & 9.86 & 7.86 & 0.26 & 0.30 & 0.31 & 0.31 & 0.29 \\
\hline JS 9305 & 2.87 & 4.97 & 5.88 & 6.12 & 4.96 & 0.27 & 0.27 & 0.29 & 0.28 & 0.28 \\
\hline JS 335 & 2.88 & 4.95 & 6.18 & 6.08 & 5.02 & 0.26 & 0.25 & 0.26 & 0.26 & 0.26 \\
\hline Mean & 3.25 & 6.03 & 7.40 & 7.30 & & 0.27 & 0.28 & 0.29 & 0.29 & \\
\hline Source & $\mathrm{SE}(\mathrm{m})$ & \multicolumn{2}{|c|}{$\mathrm{CD}(\mathrm{p}=0.05)$} & & & $\mathrm{SE}(\mathrm{m})$ & \multicolumn{2}{|c|}{$\mathrm{CD}(\mathrm{p}=0.05)$} & & \\
\hline Variety & 0.023 & 0.066 & & & & 0.002 & \multicolumn{2}{|c|}{0.005} & & \\
\hline$P$ level & 0.023 & 0.066 & & & & 0.002 & \multicolumn{2}{|c|}{0.005} & & \\
\hline $\mathbf{V X P}$ & 0.045 & 0.132 & & & & 0.003 & \multicolumn{2}{|l|}{0.01} & & \\
\hline
\end{tabular}

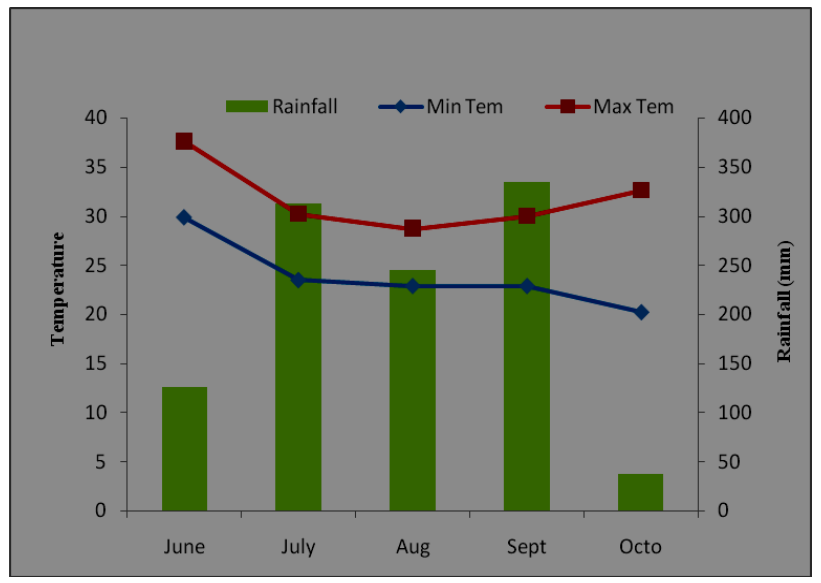

Figure.1 Weather data during the experiment 
Table.5 Phosphorus Uptake Efficiency and Phosphorus Use Efficiency as affected by treatments

\begin{tabular}{|c|c|c|c|c|c|c|c|c|c|c|}
\hline \multicolumn{6}{|c|}{ Phosphorus Uptake Efficiency } & \multicolumn{5}{|c|}{ Phosphorus Use Efficiency } \\
\hline \multicolumn{6}{|c|}{ Phosphorus levels $\left(\mathrm{kg} \mathrm{ha}^{-1}\right)$} & \multicolumn{5}{|c|}{ Phosphorus levels $\left(\mathrm{kg} \mathrm{ha}^{-1}\right)$} \\
\hline Variety & $\mathbf{P 1}$ & $\mathbf{P 2}$ & P3 & P4 & Mean & P1 & $\mathbf{P 2}$ & P3 & P4 & Mean \\
\hline JS 9560 & 0.36 & 0.45 & 0.52 & 0.48 & 0.45 & 46.13 & 56.17 & 61.91 & 49.91 & 57.94 \\
\hline JS 9752 & 0.43 & 0.57 & 0.75 & 0.73 & 0.62 & 58.70 & 74.65 & 93.75 & 84.41 & 77.88 \\
\hline JS 9305 & 0.30 & 0.55 & 0.61 & 0.46 & 0.48 & 30.47 & 52.98 & 58.46 & 42.57 & 46.12 \\
\hline JS 335 & 0.31 & 0.52 & 0.65 & 0.52 & 0.50 & 38.33 & 56.88 & 66.03 & 49.46 & 52.68 \\
\hline Mean & 0.35 & 0.52 & 0.63 & 0.55 & & 47.82 & 60.17 & 70.04 & 56.59 & \\
\hline Source & $\mathrm{SE}(\mathrm{m})$ & \multicolumn{2}{|c|}{$\mathrm{CD}(\mathrm{p}=0.05)$} & & & $\mathrm{SE}(\mathrm{m})$ & \multicolumn{2}{|c|}{$\mathrm{CD}(\mathrm{p}=0.05)$} & & \\
\hline Variety & 0.006 & 0.019 & & & & 0.52 & 1.45 & & & \\
\hline P level & 0.006 & 0.019 & & & & 0.52 & 1.45 & & & \\
\hline V X P & 0.013 & 0.037 & & & & 1.04 & 2.90 & & & \\
\hline
\end{tabular}

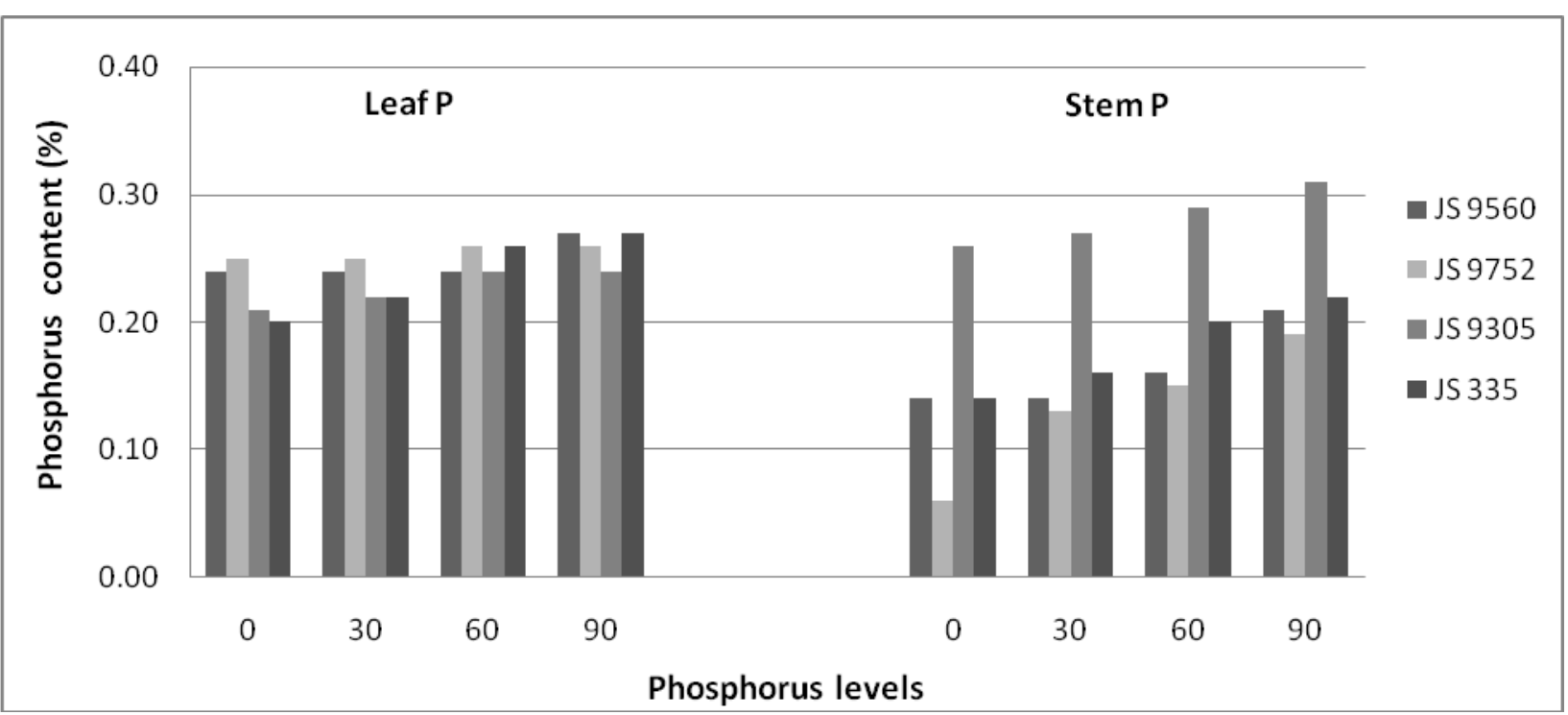

Figure.2 Leaf and Stem phosphorus content as affected by phosphorus treatments and varieties

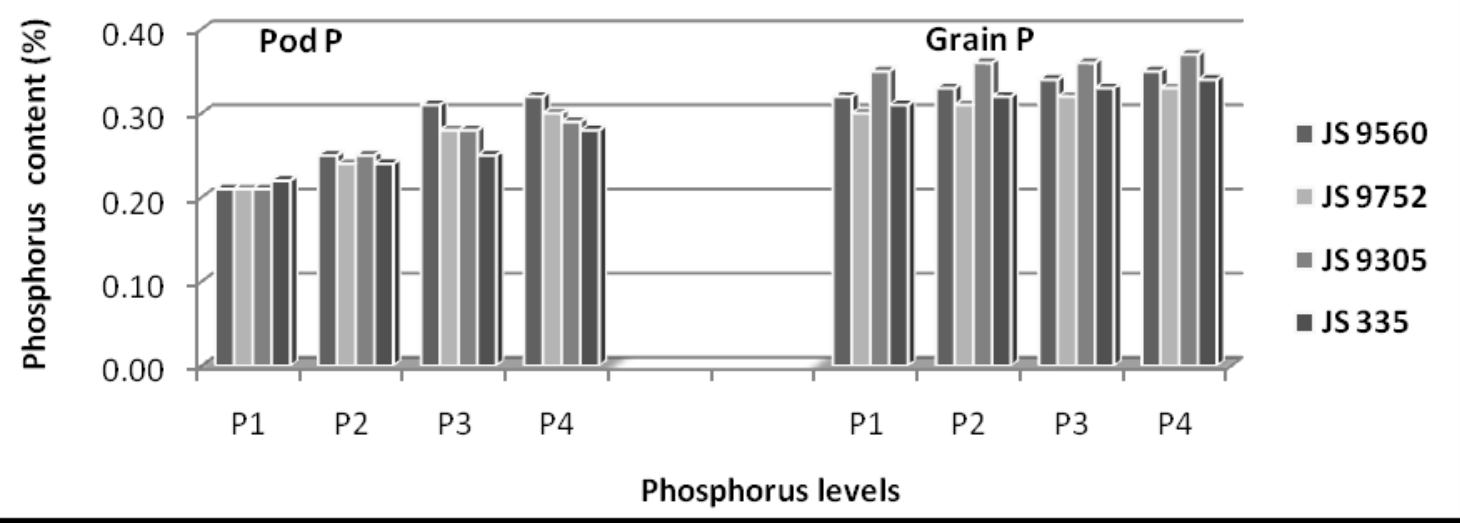

Figure.3 Pod and Grain phosphorus content as affected by phosphorus treatments and varieties 


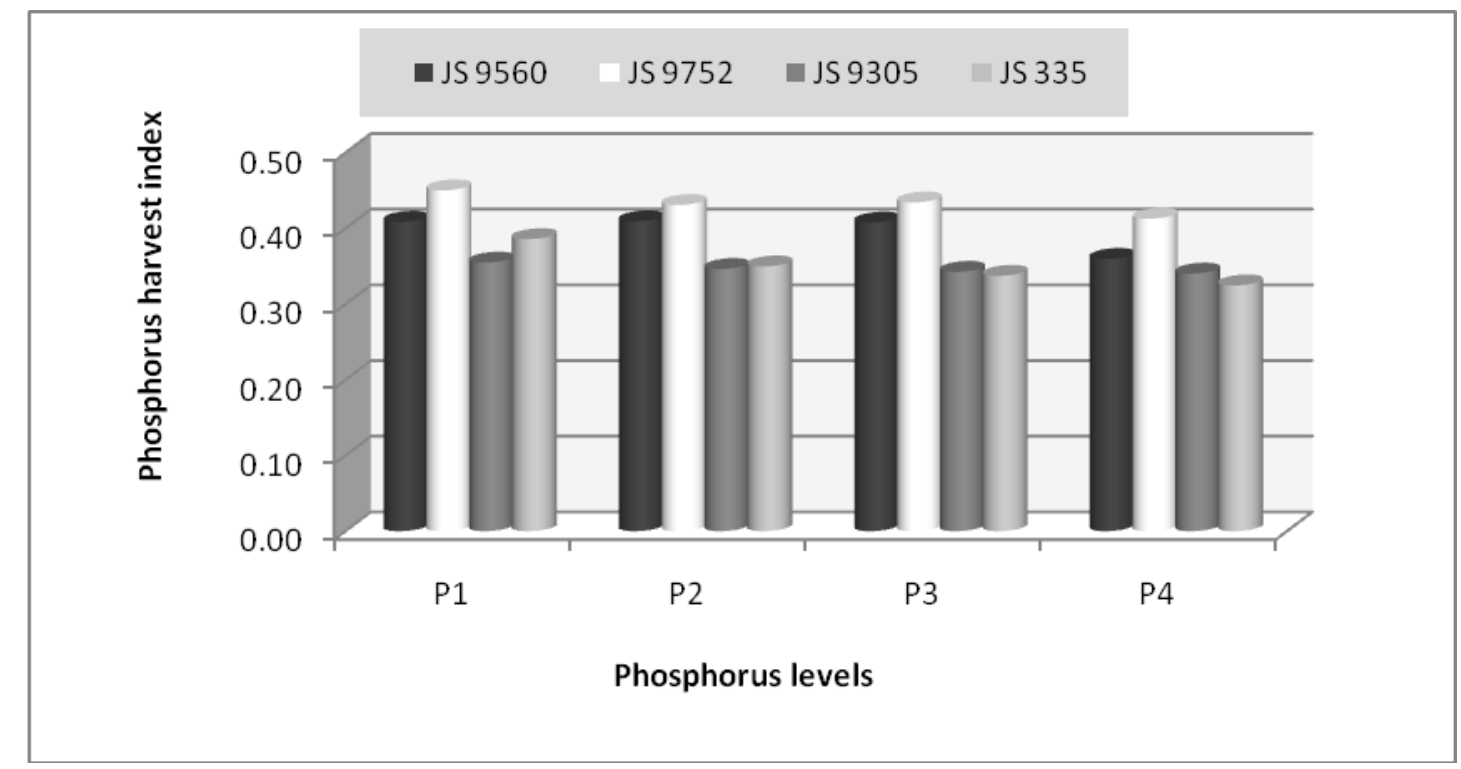

Figure.4 Phosphorus Harvest Index as affected by varieties and phosphorus application

The total phosphorus uptake also showed significant difference between treatments (Table 3). Among the varieties the highest total phosphorus uptake was recorded by JS 9752 followed by JS 9560. The phosphorus application significantly increased total phosphorus uptake by all the varieties. Similar findings were reported by Andraski and Bundy (2003) and Goswami et al., (1999). The highest $\mathrm{P}$ uptake at $\mathrm{P}$ deficient condition was shown by the variety JS 9752 and JS 9305. The uptake of the variety depends on the dry matter produced by variety and the phosphorus concentration in the tissue. Hence the more dry matter accumulation as well as the higher tissue $\mathrm{P}$ concentrations resulted in the highest uptake. Here the highest uptake was recorded by the treatment $\mathrm{P} 4\left(90 \mathrm{~kg} \mathrm{P}_{2} \mathrm{O}_{5}\right.$ $\left.\mathrm{ha}^{-1}\right)$. In soybean, there will be substantial reduction of dry matter production and $\mathrm{P}$ uptake if phosphorus is deficient during the initial growth periods (Li et al., 2010). Here the total dry matter production and the tissue phosphorus concentration showed an inverse relation because of the dilution effect inside the plant system. Similar findings were reported by Furlani et al., (2002)

The grain yield showed significant difference between treatments and varieties (Table 4). The highest grain yield was recorded by the variety JS 9752 followed by JS 9560. The phosphorus treatments also showed significant difference in case of grain yield. The highest grain yield was recorded by the treatment P3 $\left(60 \mathrm{~kg} \mathrm{P}_{2} \mathrm{O}_{5} \mathrm{ha}^{-1}\right)$, ie.. there is a gradual increase in grain yield up to $60 \mathrm{~kg}$ $\mathrm{P}_{2} \mathrm{O}_{5} \mathrm{ha}^{-1}$ and thereafter it is decreased. Similar findings were reported by Sharma et al., (1991). With no $\mathrm{P}$ application the highest yield was recorded by the variety JS 9752 followed by JS 9560.

The harvest index was also showed significant difference between treatments and varieties (Table 4). The highest harvest was recorded by the variety JS 9752 followed by JS 9560. The lowest harvest index was recorded by the variety JS 335 . The application of phosphorus increased the harvest index upto $\mathrm{P} 3\left(60 \mathrm{~kg} \mathrm{P}_{2} \mathrm{O}_{5} \mathrm{ha}^{-1}\right)$ and after that no increase in HI was observed. This may be due to the beneficial effect of phosphorus in producing higher grain yield and maintaining proper grain and plant biomass ratio. According to Malik et al., (2006) harvest index significantly varied due to phosphorus application in soybean. 
The phosphorus uptake efficiency (PUpE) presented in table 5 showed significant difference between phosphorus treatments and varieties. The highest phosphorus uptake efficiency was recorded by the variety JS 9752 followed by JS 335. Fagaria et al., (2008) reported that nutrient efficient plants can produce higher yield per nutrient applied compared to other plants. The lowest value for phosphorus uptake efficiency was recorded by the variety JS 9560 followed by JS 9305. In the case of phosphorus treatments the highest phosphorus uptake efficiency (PUpE) was recorded by the treatment receiving $\mathrm{P} 3\left(60 \mathrm{~kg} \mathrm{P}_{2} \mathrm{O}_{5} \mathrm{ha}^{-1}\right)$ and the lowest (PUpE) was shown by the treatment P1 $(0 \mathrm{~kg}$ $\mathrm{P}_{2} \mathrm{O}_{5} \mathrm{ha}^{-1}$ ). Several researchers (Shah et al., 2001; Kumar and Kushwaha, 2006; Shakralingappa et al., 2000) reported that phosphorus uptake efficiency and yield increased with phosphorus application mainly because of the higher amount of biomass production and resultant phosphorus accumulation in plant.

Phosphorus Use Efficiency (PUE) is considered as an important index in determining use of applied fertilizer by a crop species. In this study phosphorus use efficiency showed significant difference between phosphorus treatment and varieties. The highest PUE was recorded by the variety JS 9752 followed by JS 9560. The lowest PUE was recorded by the variety Js 9305 showing the least efficient variety among the four in phosphorus utilization. Among the phosphorus treatments, the highest phosphorus use efficiency was observed in the treatment $\mathrm{P} 3\left(60 \mathrm{~kg} \mathrm{P}_{2} \mathrm{O}_{5} \mathrm{ha}^{-1}\right)$ followed by $\mathrm{P} 2\left(30 \mathrm{~kg} \mathrm{P}_{2} \mathrm{O}_{5} \mathrm{ha}^{-1}\right)$. Phosphorus use efficiency parameters decreased with increasing rate of phosphorus in rice reported by Fragaria and Barbosa Filho (2007).

The phosphorus harvest index (PHI) showed significant difference between the treatments and varieties (Figure 4). The highest PHI was recorded by the variety JS 9752 followed by JS 9560. The lowest PHI was recorded by the variety JS 9305 and this might be due to the low grain phosphorus uptake of the variety. Among the phosphorus rates the treatment P1showed the highest PHI followed by P2 and P3. The lowest PHI was recorded by the treatment P4. Ao et al., (2014) reported that under moderate and high $\mathrm{P}$ levels, the high $\mathrm{P}$ efficiency cultivars were showed exceptional phosphorus agronomic efficiency and PHI.

\section{Conclusions are as follows:}

Based on the phosphorus content in different plant tissues, total dry matter production and the different phosphorus efficiency indices studied were helped to derive the most phosphorus efficient variety among the 4 high yielding promising varieties. Various studies conducted by several researchers in soybean reported the importance of the above parameters to decide the phosphorus efficient genotype. From this study it was concluded that the best cultivar which recorded the highest dry matter yields and the highest phosphorus uptake and use efficiency and have the lowest stem P concentration was JS 9752. Hence this variety can be used in breeding programme for evolving more $\mathrm{P}$ efficient cultivars.

\section{References}

Andraski, T. W., and Bundy, L G. 2003. Relationships between phosphorus levels in soil and in runoff from corn production systems. Journal of Environmental Quality. 32: 310-316.

Ao, X., Guo, X., Zhu, Q., Zhang, H., Wang, H., Ma, Z., Han, X., Zhao M., and Xie, F. 2014. Effect of phosphorus fertilization to p uptake and dry matter accumulation in soybean with different $\mathrm{P}$ efficiencies. Journal of Integrative Agriculture. 13(2): 326-334. 
Ao, X., Zhao, M.H., Zhu, Q., Li, J., Zhang, H. J., Wang, H. Y., Yu, C. M., Li, C. H., Yao, X. D., Xie, F.T., et al., 2013. Study on plant morphological traits and production characteristics of super highyielding soybean. Journal of Integrative Agriculture. 12: 1173-1182.

Cai, B.Y., Zu, W., and Ge, J.P. 2004. Influence on phosphorus amount to dry matter accumulation and distribution of different soybean cultivars. Soybean Science. 23: 73-280.

Carsky, R. J., Singh, B. B., and Oyewole, R. 2001. Contribution of early-season cowpea to late season maize in the savanna zone of West Africa. Biol. Agric. Hort. 18: 303-315.

Chauhan, Y.S., Johansen, C., and Venkataratnam, N. 1992 Effects of phosphorus deficiency on phenology and yield components of short-duration pigeon pea. Tropical Agriculture. 69: 235-238.

Chiezey, U.F., 2001. Pod abortion and grain yield of soybean (Glycine max (L) Merrill) as influenced by nitrogen and phosphorus nutrition in northern Guinea savanna zone of Nigeria. Tropical oil Seeds J. 6:1-10.

Chiezey, U.F., Yayock, J.Y., and Ahmed, M.K. 1991. Effect of phosphorus and plant density on yield and yield components of soybean (Glycine max (L) Merrill). Crop Research. 4(1):11-18.

Dinkelaker,B., Römheld,V., and Marschner,H. 1989. Citric acid excretion and precipitation of calcium citrate in the rhizosphere of white lupin (Lupinus albus L.), Plant Cell Environ. 12:285-292.

Dong, D.D., Peng, X.X., and Yan, X.L. 2004. Organic acid exudation induced by phosphorus deficiency and/or aluminium toxicity in two contrasting soybean genotypes. Physiol. Plant. 122: 190-199.

Fageria, N. K., and Barbosa Filho, M. P. 2007. Dry-matter and grain yield, nutrient uptake, and phosphorus use-efficiency of lowland rice as influenced by phosphorus fertilization. Communications in Soil
Science and Plant Analysis. 38: 12891297.

Fageria, V., Baligar, V.C., and Li, Y.C. 2008. The role of nutrient efficient plants in improving crop yields in the twenty first century. Journal of Plant Nutrition. 31 (6):1121-1157.

Furlani, A.M.C., Furlani, R.R., Tanaka,, R.T., Mascarenhas, H.A.A., and Delgado, M.D.P. 2002. Variability of soybean germplasm in relation to phosphorus uptake and use efficiency. Scientia Agricola. 59(3): 529-536.

Gomez, K.A., and Gomez, A.A. 1984. Statistical Procedures in Agricultural Research. Second Edition, Wiley, New York. p. 680.

Goswami, S., Khan, R. A., and Vyas, K. M. 1999. Response of soybean (Glycine max) to levels, sources and methods of phosphorus application. Indian Journal Agronomy. 44: 126-129.

Hodges, T., and French, V. 1985. Soyphen: soybean growth stages modeled from temperature, daylength, and water availability. Agron. J. 77: 500-505.

Jackson, M. L., 1973. Soil chemical analysis. Published by Prentice- Hall of India Pvt. Limited, New Delhi, India, 111-203.

Johnson, J.F., Vance, C.P., and Allan, D.L. 1996. Phosphorus deficiency in Lupinus albus. Altered lateral root development and enhanced expression of phosphoenol pyruvate carboxylase. Plant Physiol. 112:31-41.

Julia, C., Wissuwa, M., Kretzschmar, T., Jeong, K., and Rose, T. 2016. Phosphorus uptake, partitioning and redistribution during grain filling in rice. Annals of Botany. 118: 1151-1162.

Kumar, A., Pandey, V., Shekh, A.M., and Kumar, M. 2008. Growth and yield response of soybean (Glycine $\max$ L.) in relation to temperature, photoperiod and sunshine duration at Anand, Gujrat India. American-Eurasian Journal of Agronomy. 1(2):45-50

Kumar, Avinash, and Kushwaha, H. S. 2006. Response of pigeon pea (Cajanus cajan) 
to sources and levels of phosphorus under rainfed condition. Indian Journal of Agronomy. 51(1): 60-62.

Li, A., Guo, D., Wang, Z., and Liu, H. 2010. Nitrogen and phosphorus allocation in leaves, twigs, and fine roots across 49 temperate, subtropical and tropical tree species: A hierarchical pattern. Funct. Ecol. 24:224-232.

Malik, M. A., Cheema, M. A., Khan, H. Z., and Wahid, M. A. 2006. Growth and yield response of soybean (Glycine max L.) to seed inoculation and varying phosphorus levels. J. Agric. Res. 44(1): 47-53.

Miladinovic, J., and Đor, devi C.V. 2011. Soybean morphology and stages of development in Soybean. In: Sojaprotein (Eds) J. Miladinovic, M. Hrusti' ' c, and M. Vidi. pp.45-68.

Pal, U.R., Nnadi, L.A., and Olufajo, O.O. 1983. Response of soybean to sowing date, plant arrangement and fertilizer application in Nigerian savanna. Proceedings of the 3rd National meeting of Nigerian soybean scientists 3:108-114.

Pal, U.R., Olufajo, O.O., Nnadi, L.A., and Singh, L. 1989. Response of soybean to phosphorus, potassium and molybdenum application. J. Agricultural Science Cambridge. 112:131-136.

Park, S.E., Haigh, A.M., and Cresswall, G.C. 2000. Stem tissue phosphorus as an index of the phosphorus status of Banksia ericifolia L. Plant soil. 227 (1-2): 59-65

Rao, I.M., Ayarza, M.A., and Garcia, R. 1995. Adaptive attributes of tropical forage species to acid soils. I. Differences in plant growth, nutrient acquisition and nutrient utilization among $\mathrm{C} 4$ grasses and C3 legumes. J. Plant Nutr. 18:2135-2155.

Russell, E.W. 1973 Soil conditions and plant growth. $10^{\text {th }}$ edition, Longman, London.

Saha, S., Saha, B., Murmu, S., Pati, S., and Roy, P.B. 2014. Grain yield and phosphorus uptake by wheat as influenced by longterm phosphorus fertilization. Afr. J. Agric. Res. 9(6):607-612.

Shah, P., Kakar, K. M., and Zada, K. 2001. Phosphorus use efficiency of soybean as affected by phosphorus application and inoculation. In (W.J. Horst. Eds.). Plant Nutrition-Food Security and Sustainability of Agroecosystems. Pp. 670-671.

Shankarlingappa, B. C., Shivaraj, B., Sudhir, K., and Vishwanatha, K. P. 2000. Interaction effect of phosphorus and sulphur on uptake of nitrogen, phosphorus, potassium and by pigeonpea. (Cajanus cajan). Indian Journal of Agronomy. 45(2): 348-352.

Sharma, H., Nahatkar, S., and Patel, M.M. 1996. Constraints of soybean production in Madhya Pradesh-analysis. Bhartiya Krishi Anusandhan Patrika. 11(2): 79-84.

Sharma, U. C., and Singh, B. 1991. Effect of Applied $\mathrm{P}$ on the Yield and Incidence of Pod Blight of Soybean in Nagaland. Journal of Hill Research. 4: 94-96.

Yan, X., Liao, H., and Nian, H. 2009. Root breeding for better plant nutrient efficiency on acid soils. In: Plant-soil interactions at low $\mathrm{pH}$ : a nutriomic approach. (Eds) Liao H, Yan X, Kochian L. Guangzhou: South China University of Technology Press, pp.5-6.

\section{How to cite this article:}

Neenu, S., K. Ramesh, J. Somasundaram and Ramana, S. 2020. Varietal Influence on Phosphorus Uptake and Use Efficiency in Soybean at Varying Phosphorus Regimes in Vertisols of Central India. Int.J.Curr.Microbiol.App.Sci. 9(06): 2743-2753.

doi: https://doi.org/10.20546/ijcmas.2020.906.333 